九州大学学術情報リポジトリ

Kyushu University Institutional Repository

\title{
Poor Farmer, Entrepreneurs and ICT Relation in Production \& Marketing of Quality Vegetables in Bang ladesh
}

Ahmed, Mansur

Kyushu University-JICA Grassroots Technical Cooperation Project

Zeng, Yinchu

School of Agricultural Economics and Rural Development, Renmin University of China

Ozaki, Akinori

Institute of Tropical Agriculture, Kyushu University

Ito, Shoichi

Faculty of Agriculture, Kyushu University

他

https://doi.org/10.5109/1564129

出版情報：九州大学大学院農学研究院紀要. 61 (1)，pp.241-250，2016-02-29. Faculty of Agriculture, Kyushu University

バージョン :

権利関係 : 


\title{
Poor Farmer, Entrepreneurs and ICT Relation in Production \& Marketing of Quality Vegetables in Bangladesh
}

\author{
Mansur AHMED'1, Akinori OZAKI*, Kazuo OGATA, Shoichi ITO ${ }^{2}$, Ikuo MIYAJIMA, Ashir AHMED, \\ Takashi OKAYASU ${ }^{2}$, Dipok K. CHOUDHURY ${ }^{1}$ and Nayeen Al AMIN ${ }^{1}$
}

Institute of Tropical Agriculture, Kyushu University, Fukuoka 812-8581, Japan

(Received November 11, 2015 and accepted November 19, 2015)

\begin{abstract}
Bangladesh is a country where people mostly depend on agriculture. The crop sub-sector of agriculture mainly depends on extensive agrochemicals to increase production and to ensure the national food security. Although, farmers have been using agrochemicals, the production was still found not to increase significantly due to the lack of knowledge about proper and modern cultivation technology. In addition, farmers are getting less income from agriculture compared to another profession, because of the inconsistent price of agricultural produces between the rural and urban area. In order to improve the situation, Kyushu University has conducted JICA (Japan International Cooperation Agency) grassroots technical cooperation project which aims at income generation for BOP (Bottom of Pyramid) farmers by producing and marketing the chemical free quality vegetables using ICT (Information and Communication Technology). The project has been conducted in five rural areas in Bangladesh. Here, the farmers are producing vegetables under a quality vegetable management center (QVMC) which is well equipped with ICT tools, and a quality vegetable entrepreneur (QVE) is helping them regularly to get the desired production and also ensuring the marketing of such vegetables. The project has targeted 100 farmers for producing chemical free vegetables and already got 42 interested farmers in 1.5 years of time. It is observed that farmers get better production under this QVMC in the winter season (called "Rabi" in Bangladesh) than summer season (called "Kharif-1" in Bangladesh).
\end{abstract}

Key words: Chemical Free Production, Income Generation, Quality Vegetable Management Center

\section{INTRODUCTION}

Bangladesh is a developing country with a large number of population. About $77 \%$ of the population is living in the villages (Hossain, A. and M. Rahman, 2012). Among them, about $35.2 \%$ people of the rural is living under poverty line (Hossain et al., 2010). Here, Agriculture is the main source of food, nutrition, employment and income generation for the majority of rural people. The sector contributes $19.1 \%$ to GDP and employs $50.3 \%$ of the labor force and crop sub-sector alone accounts for $60.8 \%$ share of agricultural GDP (Mondal, 2010). The performance of the agriculture sector regulates the GDP growth rate in Bangladesh. The loss of crop production is a regular phenomenon in Bangladesh due to climate change and natural calamities like flood, cyclone, drought etc.

The soil of Bangladesh is not rich in organic matter. A fertile soil should have at least $2.5 \%$ organic matter for better production (Rahman et al., 2014). The soil of about $45 \%$ of the net cultivable area in Bangladesh has less than $1 \%$ of organic matter (Okonwu, K. and S. I. Menash, 2012). However, rural people of Bangladesh are not aware of this soil condition. Farmers have no knowledge about improving the soil condition by adding organic matter.

\footnotetext{
Kyushu University-JICA Grassroots Technical Cooperation Project, Bangladesh

Faculty of Agriculture, Kyushu University, Japan

${ }^{3}$ Department of Advanced Information Technology, Kyushu University, Japan

* Corresponding author (E-mail: a-ozaki@agr.kyushu-u.ac.jp)
}

The way of proper agricultural information flow in rural areas is very poor in Bangladesh. Farmers are getting quite less agricultural knowledge from government source due to lack of manpower. Different foreign and local NGO's are working on it, but the support is quite limited. Private sector investment in the development of agriculture is so low in Bangladesh. For this reason, our agricultural production is not satisfactory enough. To fill up this production gap, the farmers have mainly depended on agrochemicals. However, they are not getting profit from it due to more production cost and less sale price of products due to lack of proper marketing. This scenario is hindering the economic development of the rural people in Bangladesh. The alarming situation is that people are facing different health problems due to excessive use of chemical based fertilizer and pesticides.

In order to give appropriate information about the modern technology of cultivation and proper marketing of farmer's products, Kyushu University proposed a grassroot cooperation project named "Support to establish a new society of BOP farmers by using the power of ICT (SENSE)". The goal is to generate income for BOP farmers by providing the knowledge of chemical free farming technology through ICT (Information and Communication Technology) and ensuring proper marketing of farming products. The project is supported by JICA's grass root funding, implemented by Kyushu University, Japan.

The main goal of the project is to establish quality vegetable management center (QVMC) where quality vegetable entrepreneur (QVE) can provide farming and marketing information among rural farmers. The center also can help the farmers to sell their products in the urban 
and local area to generate more income.

\section{METHODS OF THE PROJECT}

\section{About SENSE project}

SENSE project is three-year project proposed by Kyushu University, Japan and funded by JICA. The project has started in January 2014 and will be ended in December 2016. The project has established in five model villages; Ekhlaspur (Chandpur), Kapasia (Gazipur), Manohardi (Narshingdi), Mirzapur (Tangail) and Basundia (Jessore). Information of these model villages is shown in Fig. 1. The objective of the project is to assist the BOP farmers to produce quality vegetables by using organic compost and organic pesticides. The project supports the whole marketing of the products to generate more income of the farmers by using different tools of ICT. The project is collaborated with four local partners; WIN-incorporate,

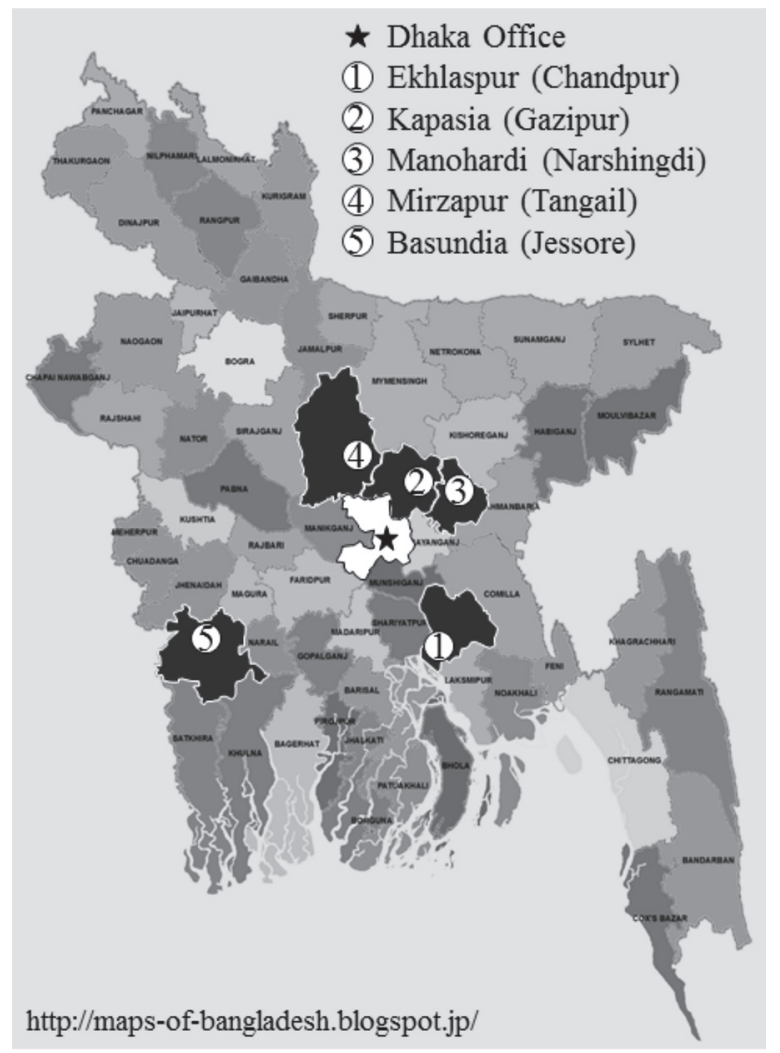

Fig. 1. Model Village of SENSE.
Grameen Communications, Bangabandhu Sheikh Mujibur Rahman Agricultural University (BSMRAU) and Bangladesh Agricultural Research Institute (BARI). The outline and the role of each collaborative partner are shown in Table 1. The project equipped with its main office in Dhaka (capital of Bangladesh) and local offices in each model villages. The office in Dhaka got 6 regular employees: one coordinator (a role of a general manager and to coordinate with the partnering organizations), one marketing manager (to create marketplace for farming products), two marketing officer (to assist the marketing manager), one technical manager (to answer the farmer's queries by using ICT) and one technical administrator (to maintain the ICT setup in main office and local quality vegetable management center). In the field i.e. in each project site there is one QVE. QVE has monitored farmers' activity, advised the farmers and assisted the marketing of farming products. Detail organization of SENSE is shown in Fig. 2.

\section{Quality Vegetable Management Center as connect- ing hub}

A quality vegetable management center (QVMC) has been established in each villages. The QVMC is the gathering point of the farmers and a QVE is regularly there to help the farmers. A monthly meeting has been arranged in the QVMC about recent and upcoming farming activities. The farmers have got the following help from the QVMC:

1. Modern cultivation information about vegetables

2. Fertilizer and manure management information

3. Crop and variety selection

4. Diseases and insects control measure

5. Sale information of products

6. Selling the farming products

\section{ACHIEVEMENTS OF THE PROJECT}

\section{ICT activities}

ICT applications

ICT applications have been used as information platform for cultivation and marketing of the products. Mainly five ICT applications have been used by both farmers and QVE Features and usage of five ICT applications are described below (Fig. 4).

(1) "E-agriculture" is a medium where the QVE upload farming activities in both English and Bengali lan-

Table 1. Information of collaborative partner

\begin{tabular}{|c|c|c|c|c|}
\hline $\begin{array}{l}\text { Collaborative } \\
\text { partner }\end{array}$ & BSMRAU & Communications & 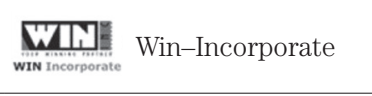 & (1) \\
\hline $\begin{array}{l}\text { Outline for } \\
\text { Organization }\end{array}$ & $\begin{array}{l}\text { BSMRAU aims to contribute } \\
\text { to agricultural research } \\
\text { system and dissemination of } \\
\text { agricultural technique and } \\
\text { knowledge thorough research, } \\
\text { training and field activity. }\end{array}$ & $\begin{array}{l}\text { Grameen communications is a } \\
\text { core organization of ICT in } \\
\text { Grameen family and develop } \\
\text { ICT infrastructure including } \\
\text { tele-center network in } \\
\text { Bangladesh. }\end{array}$ & $\begin{array}{l}\text { Win-Incorporate provide } \\
\text { agricultural technical } \\
\text { knowledge and marketing } \\
\text { information through internet } \\
\text { and contribution to } \\
\text { development of farming } \\
\text { business. }\end{array}$ & $\begin{array}{l}\text { BARI is the largest multi-crop } \\
\text { research institute conducing } \\
\text { research on a wide variety of } \\
\text { crops and management of } \\
\text { crop, soil water etc. }\end{array}$ \\
\hline Role of SENSE & $\begin{array}{l}\text { provision amd teaching if } \\
\text { agricultural technique }\end{array}$ & $\begin{array}{l}\text { Construction for ICT } \\
\text { environment }\end{array}$ & Development of ICT contents & $\begin{array}{l}\text { Providing soil \& product } \\
\text { testing and certification }\end{array}$ \\
\hline
\end{tabular}




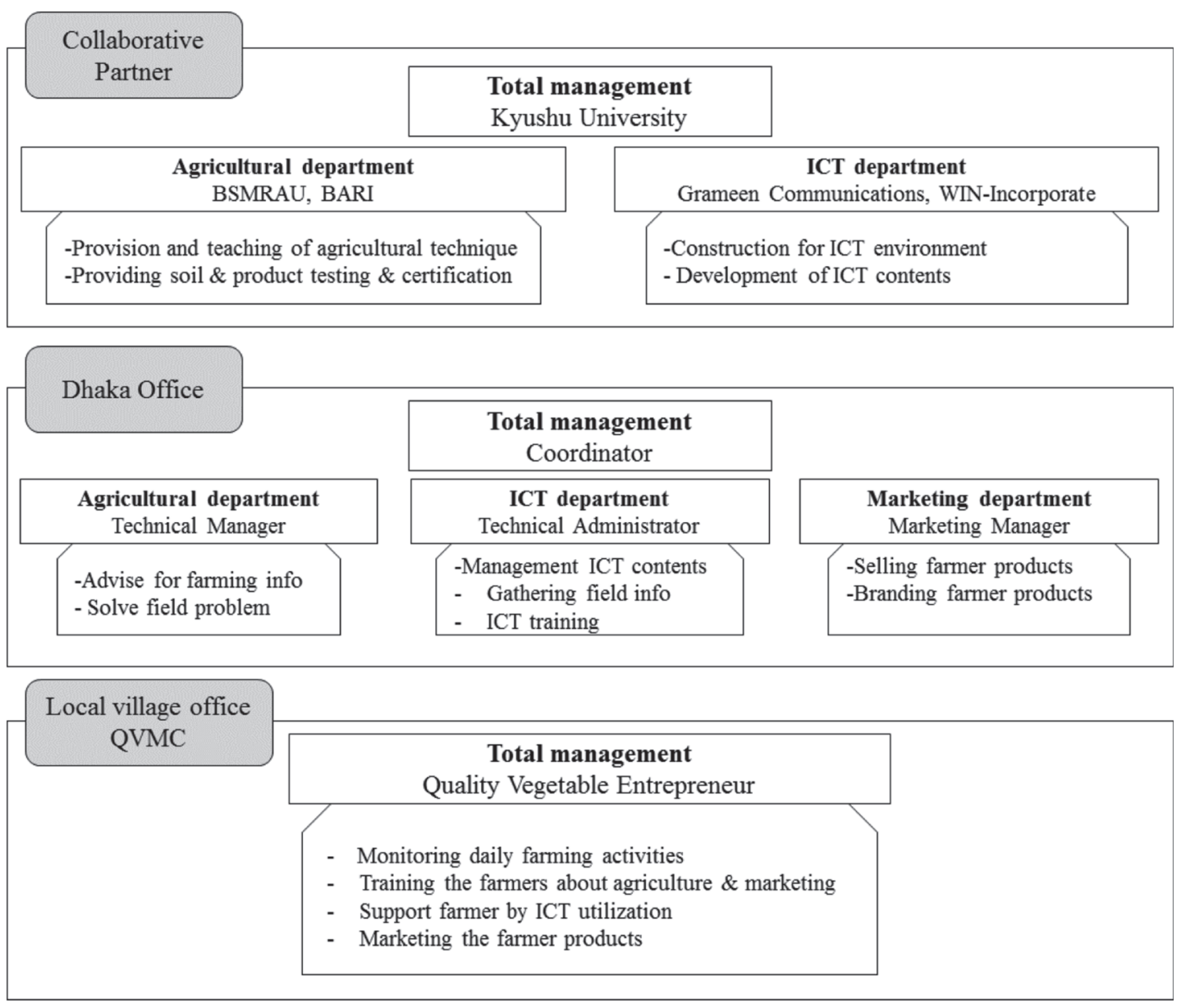

Fig. 2. Organization of SENSE.
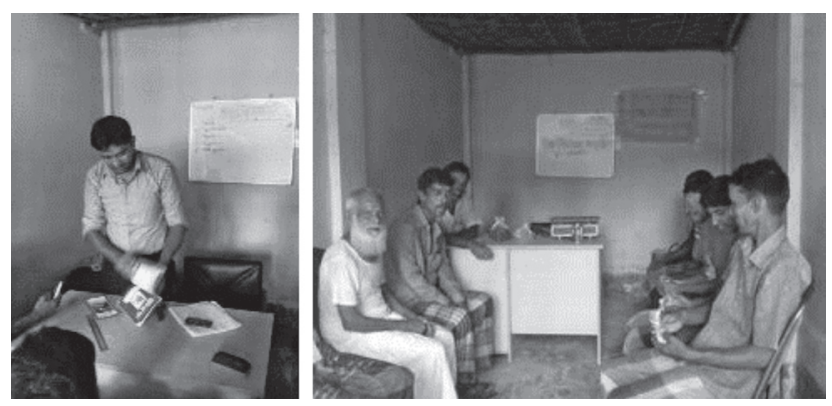

Fig. 3. QVMC of Mirzapur, Tangail.

guage (for better understanding of the farmers). It is also communication hub among the farmers, expert and market agent. By using E-agriculture farmers can get immediate solutions of their problems from agriculture experts (Fig. 5).

(2) "Digital content of learning" is supporting contents of chemical free cultivation method of different seasonal vegetables. The contents have been prepared and updated by our agriculture experts. The cultivation knowledge from the digital contents of learning is used by QVE to teach the farmer about proper cultivation. Farmers are also getting updated information from this content.

(3) E-commerce is a marketplace of quality vegetable where the consumer can purchase the products. In addition consumers can see the farming activities and ensure the products safety. It can reduce the intermediaries' activities as this result it can increase the income of farmers.

(4) Agri-eye is a farm environment monitoring system which can provide decision-making information in farming. The data from the Agri-eye can be used to predict the harvesting time of vegetables and the pattern of different insect pest infestation. Fig. 6 shows example temperature and humidity data obtained at Ekhlaspur in Kharif-1 season.

(5) Android information gathering system is a smartphone based application which is used for gathering farming information by text (both English and Bengali) and images. In addition, a real time alert option is available in the application to tell the farmers about weather and market conditions. Android information gathering system is the data entry point of farming activities and a portable learning medium of agriculture and marketing information. Through this system, the farmers can easily send their problems for knowing the solutions immediately. In addition, farmers are getting some alert message through this application (Fig. 7). An android based Tab is being used by QVE to gather the information of farming activities. 


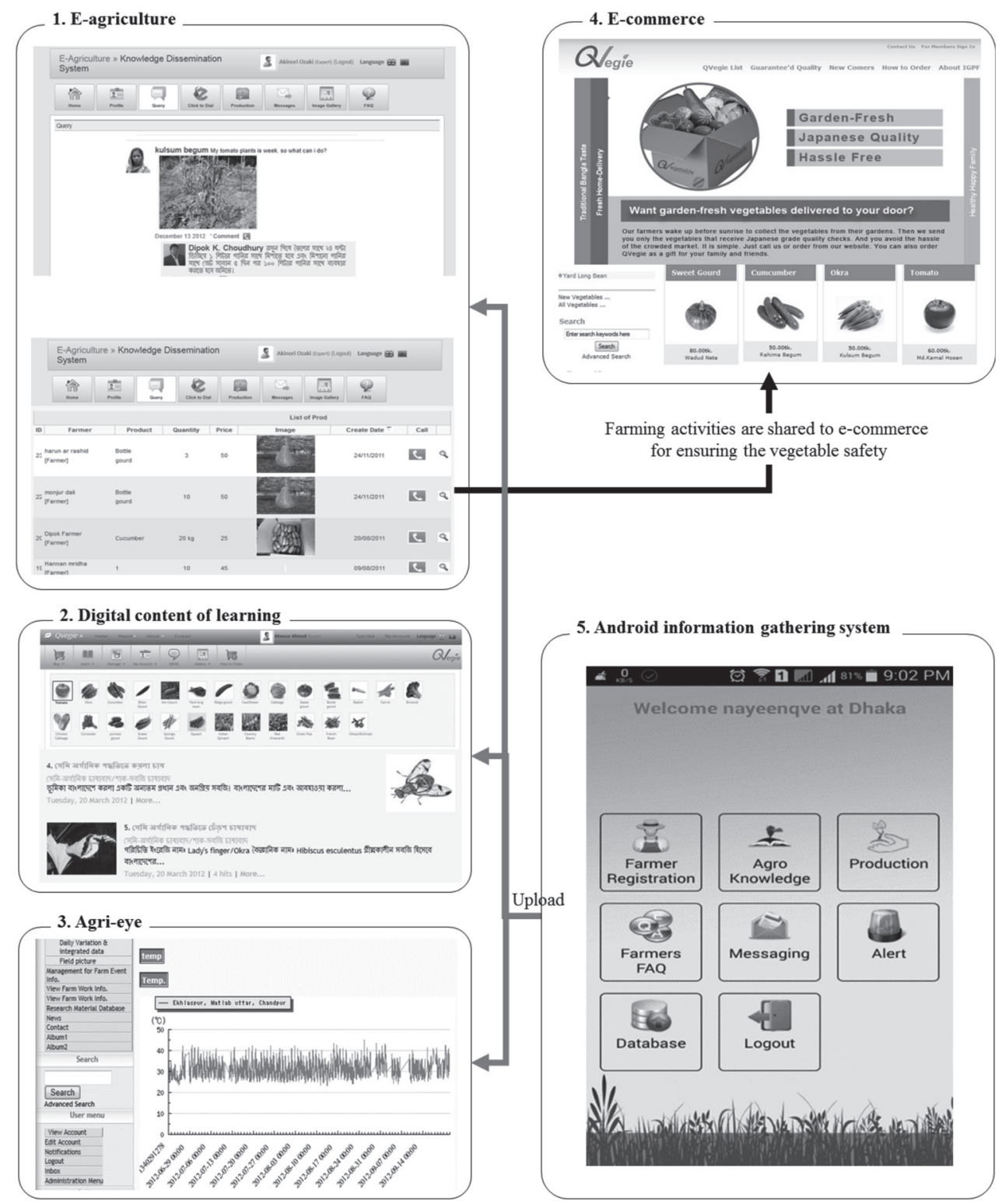

Fig. 4. ICT applications of SENSE.
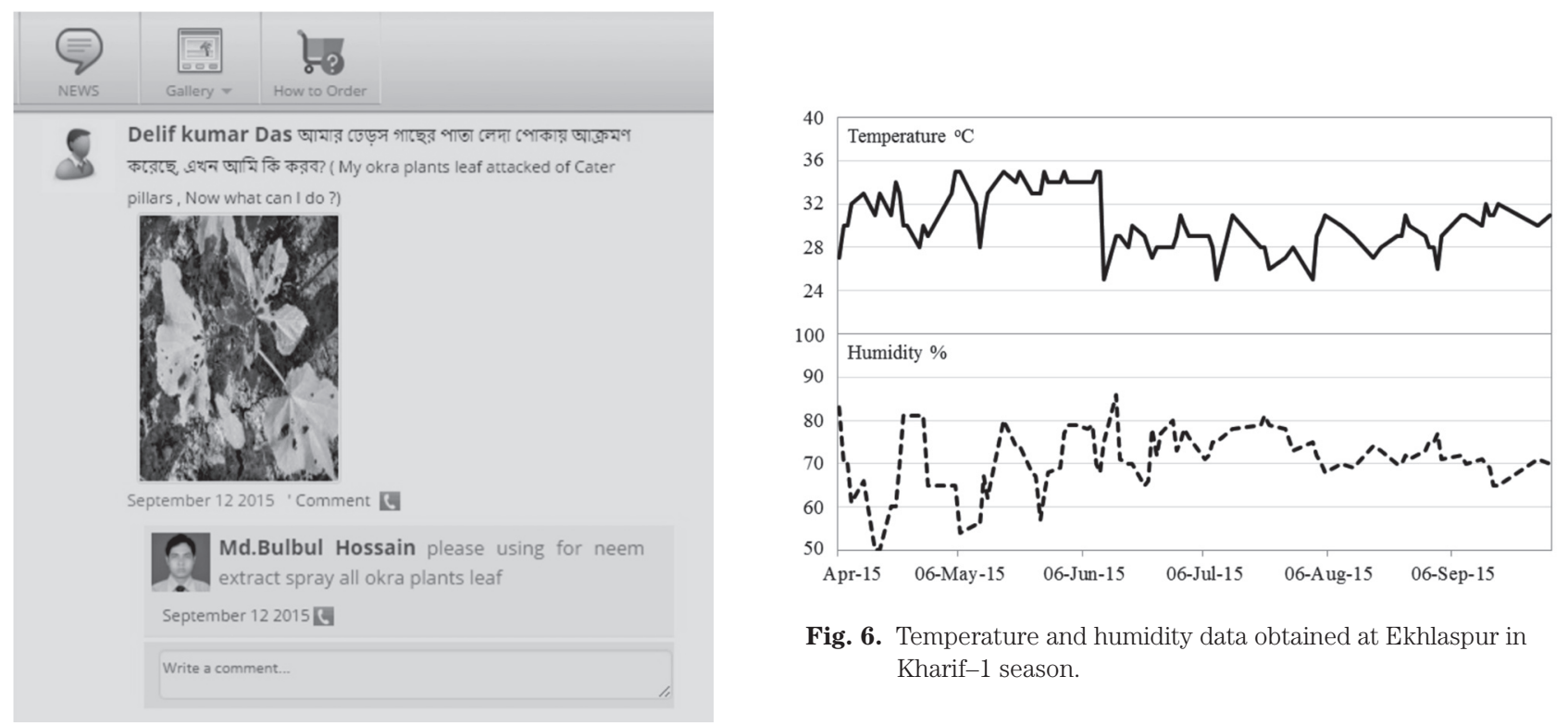

Fig. 6. Temperature and humidity data obtained at Ekhlaspur in Kharif-1 season.

Fig. 5. Answer farmers' problem by experts. 

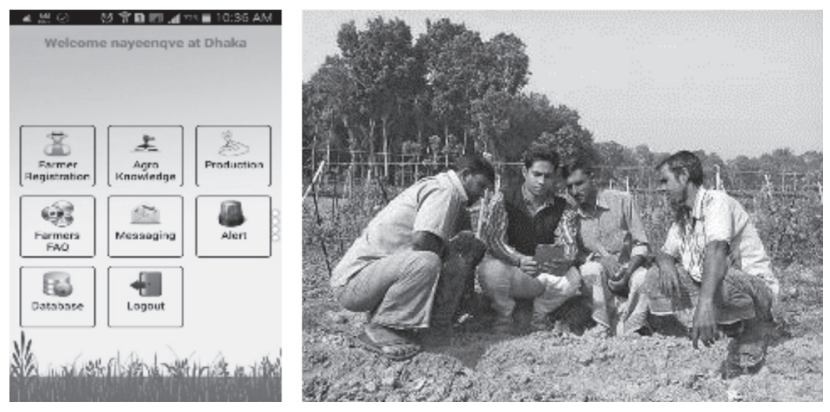

Fig. 7. Android application for farmers.

\section{Agricultural activities \\ Agriculture training and courtyard meeting}

SENSE project has informed the farmers about artificial agrochemical free modern cultivation method and asked their participation in the project. The project has designed to facilitate 100 model farmers from 5 model villages in which 20 farmers should join from each village. After explanation of our activities, about 72 farmers have agreed to cultivate agricultural produces following the project model. Two leader farmers has been selected in each site based on their ability to motivate others. Within the project, a training program has been arranged at BSMRAU to train the farmers about the proper way of cultivation. After that, QVE and leader farmers have arranged follow up training programs at their respective sites. Leader farmers and QVE shared their learning of modern way of cultivation to farmers who were interested in modern cultivation methods. The table shows the previous training information (Table 2).

A courtyard meeting has been regularly arranged in every month by QVE and leader farmers in each site. QVE and leader farmers have shared the recent and forthcoming information related to cultivation in the meeting. Sometimes, local government agricultural staffs also volunteered to train the farmers. QVE has regularly visited the farming fields, solved the farmers' problems and advised the farming activities.

\section{Farming activities}

The farmers have produced vegetables mainly in two seasons named Kharif-1(16 March to 15 July) and Rabi (16 October to 15 March). The cultivation season is shown in Table 3. The season wise vegetable list is shown in Table 4. The farmers have followed different companion cultivation method to produce quality vegetables. Some cultivation activities of the project are shown in Fig. 8.

\section{Results of harvesting}

During the first 1.5 years of implementation term,

Table 2. SENSE agricultural training

\begin{tabular}{|c|c|c|c|}
\hline Training & Date & Contents & Participants \\
\hline $\begin{array}{l}\text { Explanatory meeting } \\
\text { at Ekhlaspur }\end{array}$ & 1-4 April 2014 & Introduction of basic concepts of SENSE & SENSE staff: 8 \\
\hline BSMRAU training & $\begin{array}{l}25-27 \text { August } \\
2014\end{array}$ & $\begin{array}{l}\text { Training of cultivation technology, pest management and } \\
\text { post-harvest management of summer and winter vegetables }\end{array}$ & $\begin{array}{l}\text { Representative model farmer: } 10 \\
\text { SENSE staff: } 9\end{array}$ \\
\hline $\begin{array}{l}\text { Local training } \\
\text { at Ekhlaspur }\end{array}$ & 10 Nov 2014 & $\begin{array}{l}\text { Training of cultivation technology, pest management and } \\
\text { post-harvest management of summer and winter vegetables }\end{array}$ & $\begin{array}{l}\text { Ekhlaspur model farmer: } 11 \\
\text { SENSE staff: } 1\end{array}$ \\
\hline $\begin{array}{l}\text { Local training } \\
\text { at Kapasia }\end{array}$ & 10 Nov 2014 & $\begin{array}{l}\text { Training of cultivation technology, pest management and } \\
\text { post-harvest management of summer and winter vegetables }\end{array}$ & $\begin{array}{l}\text { Kapasia model farmer: } 15 \\
\text { SENSE staff: } 1\end{array}$ \\
\hline $\begin{array}{l}\text { Local training } \\
\text { at Manohardi }\end{array}$ & 10 Nov 2014 & $\begin{array}{l}\text { Training of cultivation technology, pest management and } \\
\text { post-harvest management of summer and winter vegetables }\end{array}$ & $\begin{array}{l}\text { Manohardi model farmer: } 6 \\
\text { SENSE staff: } 1\end{array}$ \\
\hline $\begin{array}{l}\text { Local training } \\
\text { at Basundia }\end{array}$ & 10 Nov 2014 & $\begin{array}{l}\text { Training of cultivation technology, pest management and } \\
\text { post-harvest management of summer and winter vegetables }\end{array}$ & $\begin{array}{l}\text { Basundia model farmer: } 20 \\
\text { SENSE staff: } 1\end{array}$ \\
\hline $\begin{array}{l}\text { Local training } \\
\text { at Mirzapur }\end{array}$ & 10 Nov 2014 & $\begin{array}{l}\text { Training of cultivation technology, pest management and } \\
\text { post-harvest management of summer and winter vegetables }\end{array}$ & $\begin{array}{l}\text { Mirzapur model farmer: } 20 \\
\text { SENSE staff: } 1\end{array}$ \\
\hline
\end{tabular}

Table 3. Cultivation seasons for SENSE

\begin{tabular}{lll}
\hline \multicolumn{1}{c}{ Season } & \multicolumn{1}{c}{ Status } & \multicolumn{1}{c}{ Duration } \\
\hline $\begin{array}{l}\text { Winter season } \\
\text { (Rabi) }\end{array}$ & Cropping & 15 Oct 2014-15 Nov 2014 \\
\hline $\begin{array}{l}\text { Kharif season } \\
\text { (Kharif-1) }\end{array}$ & Cropping & 10 March 2015-20 April 2015 \\
\hline
\end{tabular}

Table 4. Season wise cultivated vegetables

\begin{tabular}{|c|c|}
\hline Cropping Season & Vegetables \\
\hline $\begin{array}{l}\text { Summer } \\
\text { (Kharif-1) }\end{array}$ & $\begin{array}{l}\text { Snake gourd, Ridge gourd, Bottle gourd, Sweet } \\
\text { gourd, Pointed gourd, Coriander gourd, Sponge } \\
\text { gourd, Okra, Yard long bean, Spinach, Cucumber, } \\
\text { Bitter gourd }\end{array}$ \\
\hline Winter (Rabi) & $\begin{array}{l}\text { Cabbage, Cauliflower, Tomato, Lettuce, Broccoli, } \\
\text { Chinese cabbage, Carrot, Radish, Coriander, } \\
\text { Sweet gourd, Bottle gourd }\end{array}$ \\
\hline
\end{tabular}




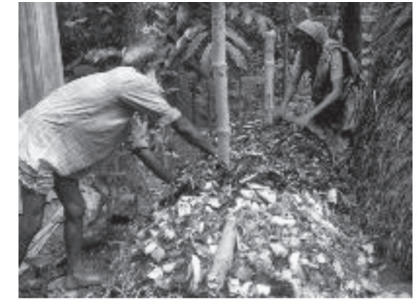

Organic compost preparation

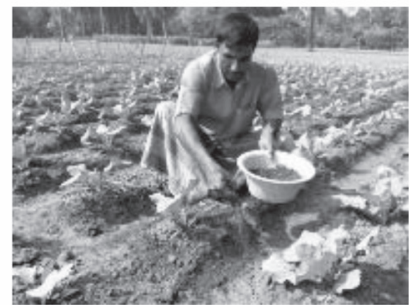

Compost application

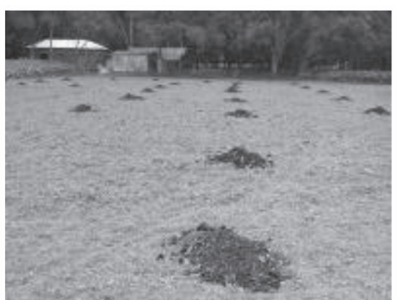

Main field preparation

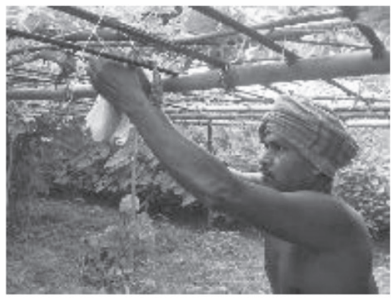

Covering for protecting from insects

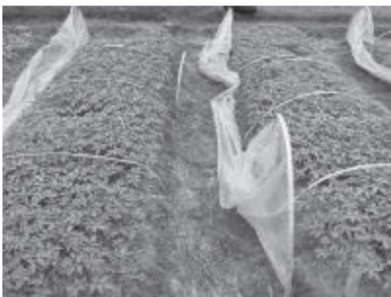

Seedlings in Seedbed

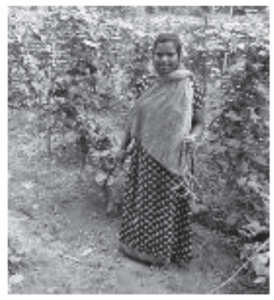

Harvesting vegetables

Fig. 8. Cultivation activities by using organic compost and organic pesticides.

Table 5. Yield amount of winter season (Rabi) 2014-15

\begin{tabular}{|c|c|c|c|c|c|}
\hline Location & Cropping term & Products & Yield amount & No. of farmers & Land area $\left(\mathrm{m}^{2}\right)$ \\
\hline Ekhlaspur & $\begin{array}{l}\text { Winter (Rabi) } \\
2014-15\end{array}$ & $\begin{array}{l}\text { Cabbage (Pcs) } \\
\text { Cauliflower (Pcs) } \\
\text { Tomato (kg) } \\
\text { Carrot (kg) } \\
\text { Radish (kg) } \\
\text { Bottle gourd (pcs) } \\
\text { Chinese Cabbage (Pcs) } \\
\text { Broccoli (Pcs) } \\
\text { Lettuce (Pcs) }\end{array}$ & $\begin{array}{r}1852 \\
1744 \\
3109 \\
120 \\
360 \\
590 \\
750 \\
490 \\
300\end{array}$ & 11 & 3702.09 \\
\hline Kapasia & & $\begin{array}{l}\text { Cabbage (Pcs) } \\
\text { Cauliflower (Pcs) } \\
\text { Tomato (kg) } \\
\text { Bottle gourd (pcs) }\end{array}$ & $\begin{array}{r}2227 \\
2082 \\
1080 \\
680 \\
\end{array}$ & 15 & 3115.42 \\
\hline Manohardi & & $\begin{array}{l}\text { Cabbage (Pcs) } \\
\text { Cauliflower (Pcs) } \\
\text { Tomato (kg) } \\
\text { Carrot (kg) } \\
\text { Radish (kg) } \\
\text { Bottle gourd (pcs) } \\
\text { Sweet gourd (Pcs) }\end{array}$ & $\begin{array}{r}225 \\
200 \\
120 \\
48 \\
110 \\
195 \\
90\end{array}$ & 6 & 669.61 \\
\hline Mirzapur & & $\begin{array}{l}\text { Cabbage (Pcs) } \\
\text { Cauliflower (Pcs) } \\
\text { Tomato (kg) } \\
\text { Carrot (kg) } \\
\text { Radish (kg) } \\
\text { Bottle gourd (pcs) } \\
\text { Sweet gourd (Pcs) }\end{array}$ & $\begin{array}{r}394 \\
2284 \\
205 \\
105 \\
1237 \\
862 \\
166\end{array}$ & 20 & 3924.62 \\
\hline Basundia & & $\begin{array}{l}\text { Cabbage (Pcs) } \\
\text { Cauliflower (Pcs) } \\
\text { Tomato (kg) } \\
\text { Bottle gourd (pcs) }\end{array}$ & $\begin{array}{r}574 \\
6057 \\
1760 \\
416\end{array}$ & 20 & 4248.30 \\
\hline
\end{tabular}

the farmers cultivated two seasons. The yield data of Rabi and Kharif-1 is shown in Table 5 \& 6, respectively. The yield was decreased in the Kharif-1 season due to frequent heavy rain. The production in Mirzapur (Tangail) was more satisfactory although heavy rain and insect infestation were the major problems. The main reason was the farmers of Mirzapur were very cooperative with QVE to execute his instructions.

\section{Marketing activities}

Grading and packaging

SENSE project has emphasized to generate more income for the BOP farmers by selling quality vegetables. A training session for the farmers on grading and packaging has been arranged at BSMRAU. A grading manual was made to teach the farmers about saleable grades. Three-way of grading has been followed during product purchase from the farmers to selling the products in the 
Table 6. Yield amount of summer season (Kharif-1) 2015

\begin{tabular}{|c|c|c|c|c|c|}
\hline Location & Cropping term & Products & Yield amount & No. of farmers & Land area $\left(\mathrm{m}^{2}\right)$ \\
\hline Ekhlaspur & $\begin{array}{l}\text { Summer } \\
\text { (Kharif-1) } 2015\end{array}$ & $\begin{array}{l}\text { Bitter gourd (kg) } \\
\text { Cucumber (kg) } \\
\text { Okra (kg) } \\
\text { Yard ling beam }(\mathrm{kg}) \\
\text { Ash gourd (kg) } \\
\text { Ridge gourd (kg) } \\
\text { Sponge gourd (kg) }\end{array}$ & $\begin{array}{l}62.5 \\
160 \\
136 \\
133.9 \\
230 \\
12 \\
130\end{array}$ & 9 & 1820.70 \\
\hline Kapasia & & $\begin{array}{l}\text { Bitter gourd (kg) } \\
\text { Cucumber (kg) } \\
\text { Okra (kg) } \\
\text { Ridge gourd (kg) } \\
\text { Sponge gourd (kg) } \\
\end{array}$ & $\begin{array}{l}40 \\
88 \\
86.5 \\
14 \\
61.9 \\
\end{array}$ & 6 & 1254.26 \\
\hline Manohardi & & $\begin{array}{l}\text { Bitter gourd (kg) } \\
\text { Cucumber (kg) } \\
\text { Okra (kg) } \\
\text { Yard ling beam (kg) } \\
\text { Ash gourd (kg) } \\
\text { Snake gourd (kg) } \\
\text { Indian spinach (kg) }\end{array}$ & $\begin{array}{r}15.1 \\
32.9 \\
76 \\
164.4 \\
62.5 \\
65.8 \\
74.6 \\
\end{array}$ & 6 & 1335.18 \\
\hline Mirzapur & & $\begin{array}{l}\text { Bitter gourd (kg) } \\
\text { Cucumber (kg) } \\
\text { Okra (kg) } \\
\text { Yard ling beam (kg) } \\
\text { Ash gourd (kg) } \\
\text { Ridge gourd (kg) } \\
\text { Sponge gourd (kg) } \\
\text { Sweet gourd }\end{array}$ & $\begin{array}{l}490 \\
154.5 \\
252 \\
187.3 \\
140 \\
136.5 \\
291 \\
504\end{array}$ & 10 & 2023 \\
\hline Basundia & & $\begin{array}{l}\text { Cucumber (kg) } \\
\text { Okra (kg) } \\
\text { Yard ling beam (kg) } \\
\text { Ridge gourd (kg) } \\
\text { Pointed gourd (kg) } \\
\text { Snake gourd (kg) } \\
\text { Sponge gourd (kg) }\end{array}$ & $\begin{array}{c}20 \\
139.75 \\
61 \\
60.5 \\
123 \\
44 \\
227\end{array}$ & 7 & 2023 \\
\hline
\end{tabular}

market. Initially, the farmers have graded their own product and then QVE has made another grade for sending the product to Dhaka. Finally, an ultimate grading has been done in Dhaka by marketing personnel of the project. Through these three-way the products have been divided into three grade namely rejected, standard and premium. The rejected graded products has been using for composting and also using as animal feed. The premium and standard graded products have being sold in Dhaka by marketing team. Also, some quantity of the premium and standard graded products has being sold in local market of the villages by farmers. Table 7 shows

Table 7. Product grading information of Dhaka marketing

\begin{tabular}{|c|c|c|c|c|}
\hline $\begin{array}{l}\text { Cropping } \\
\text { term }\end{array}$ & Vegetable & Before Grading (kg) & $\begin{array}{l}\text { Local Grading } \\
\text { Passed (kg) }\end{array}$ & $\begin{array}{l}\text { Dhaka Grading } \\
\text { Passed (kg) }\end{array}$ \\
\hline $\begin{array}{l}\text { Winter (Rabi) } \\
\text { 2014-15 }\end{array}$ & $\begin{array}{l}\text { Radish } \\
\text { Bottle Gourd } \\
\text { Sweet gourd } \\
\text { Cabbage } \\
\text { Cauliflower } \\
\text { Tomato } \\
\text { Broccoli } \\
\text { Chinese cabbage } \\
\text { Lettuce } \\
\text { Carrot }\end{array}$ & $\begin{array}{r}290 \\
195 \\
36 \\
795 \\
638 \\
1044 \\
433 \\
612 \\
77 \\
92 \\
\end{array}$ & $\begin{array}{r}229 \\
171 \\
35 \\
721 \\
582 \\
921.5 \\
382 \\
540 \\
65 \\
73 \\
\end{array}$ & $\begin{array}{r}195 \\
156 \\
33 \\
651 \\
462 \\
829 \\
334 \\
470 \\
62 \\
59 \\
\end{array}$ \\
\hline $\begin{array}{l}\text { Summer } \\
\text { (Kharif-1) } \\
2015\end{array}$ & $\begin{array}{l}\text { Ash gourd } \\
\text { Bitter gourd } \\
\text { Cucumber } \\
\text { Indian Spinach } \\
\text { Okra } \\
\text { Pointed gourd } \\
\text { Ridge gourd } \\
\text { Snake gourd } \\
\text { Sponge gourd } \\
\text { Sweet gourd } \\
\text { yard long bean }\end{array}$ & $\begin{array}{r}139 \\
163 \\
211 \\
49 \\
270 \\
126 \\
99 \\
72 \\
213 \\
388 \\
227\end{array}$ & $\begin{array}{r}100 \\
101 \\
138 \\
44 \\
210 \\
118 \\
72 \\
62 \\
155 \\
388 \\
161\end{array}$ & $\begin{array}{r}96 \\
82 \\
102 \\
43 \\
174 \\
112 \\
52 \\
60 \\
127 \\
380 \\
132\end{array}$ \\
\hline
\end{tabular}




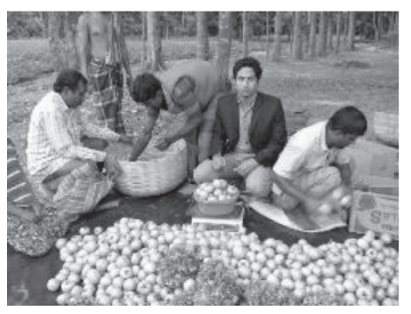

Local grading

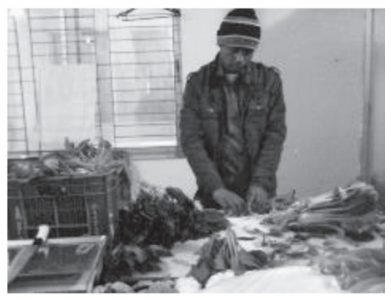

Dhaka grading
Fig. 9. Grading of vegetables.

Table 8. Transport cost from local site to Dhaka office

\begin{tabular}{llcc}
\hline Cropping term & Location & $\begin{array}{c}\text { Quantity } \\
(\mathrm{kg} / \mathrm{Pcs})\end{array}$ & $\begin{array}{c}\text { Transport cost } \\
(\mathrm{Tk})\end{array}$ \\
\hline Winter (Rabi) & Ekhlaspur & 2,029 & 8,720 \\
$2014-15$ & Kapasia & 513 & 4,650 \\
& Manohardi & 158 & 1,250 \\
& Mirzapur & 541 & 4,121 \\
& Basundia & 405 & 4,230 \\
\hline Summer & Ekhlaspur & 249 & 4,425 \\
(Kharif-1) & Kapasia & 135 & 2,660 \\
2015 & Manohardi & 190 & 2,790 \\
& Mirzapur & 640 & 7,662 \\
& Basundia & 344 & 8,121 \\
\hline
\end{tabular}

the grading difference between the local and Dhaka.

Regarding the method of package, bamboo or paper bags have been used for packaging the products in local. While plastic crates have been used to bring the products from the local site to Dhaka. Final delivery packaging have been done by plastic bag or wrapping paper in Dhaka.

\section{Supply chain}

The project has been functioning well in terms of selling the product in the rural areas due to less transportation cost and it was found more expensive while selling them in Dhaka because of high transportation cost. The
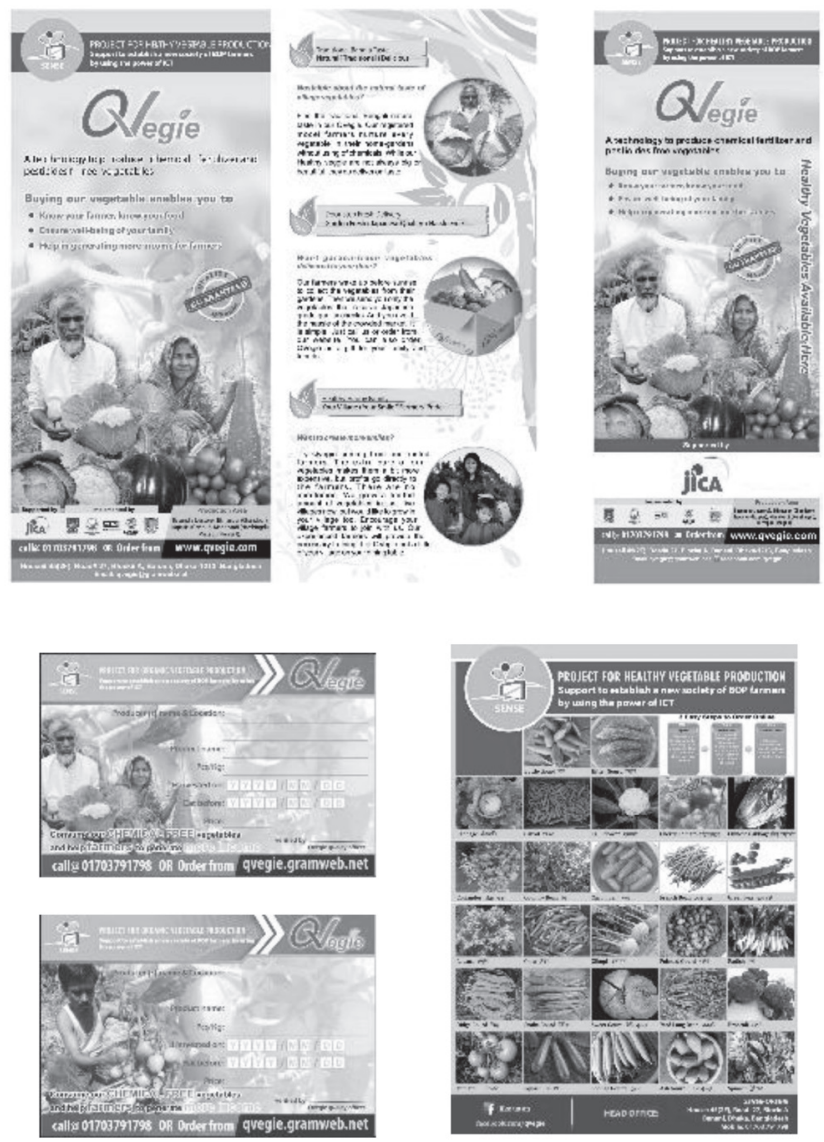

Fig. 11. Q-Vegie leaflet, Portable stand banner, sticker \& product catalog.

project is still trying to find an efficient way to sale the product in Dhaka at lower transportation cost which should help the farmers getting more benefits. The way of the supply chain is shown in Fig. 10.

\section{Branding of products}

The project has created own branding name Q-Vegie i.e. Quality Vegetable, a unique brand which provides the

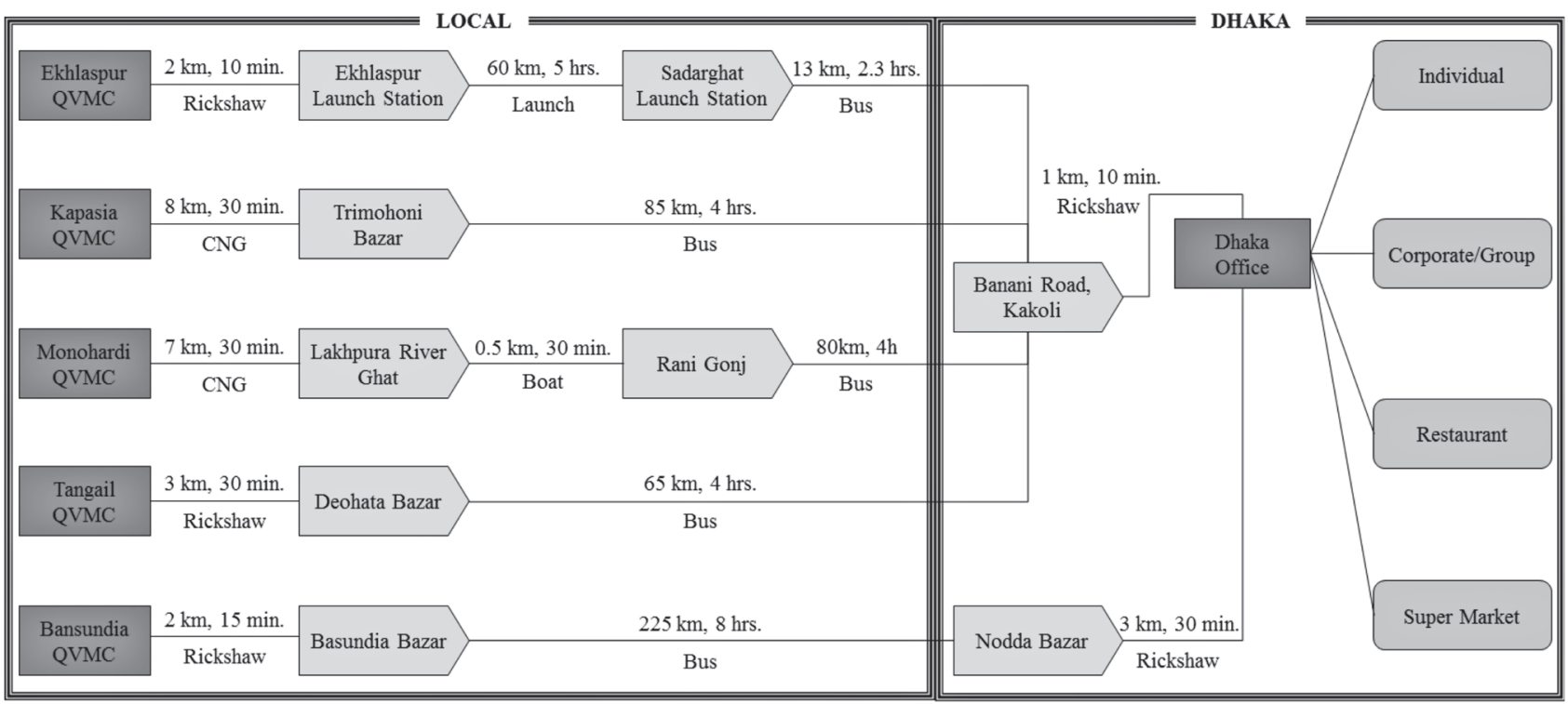

Fig. 10. Supply chain of SENSE. 
Table 9. Customer segment of SENSE

\begin{tabular}{llc}
\hline \multicolumn{1}{c}{ Cropping term } & Customer Type & Customer Number \\
\hline Winter (Rabi) & Individual & 54 \\
$2014-15$ & Group/Corporate & 4 \\
& Restaurant & 2 \\
& Super Store & 1 \\
\hline \multirow{2}{*}{ Summer (Kharif-1) } & Individual & 43 \\
2015 & Group/Corporate & 3 \\
& Restaurant & 0 \\
& Super Store & 2 \\
\hline
\end{tabular}

farmer details and location in its sticker. It indicates expiry date of the products to taste the real taste of the products. In addition, different promotion material such as leaflets, product catalogue, sticker and banner have been used for promotion of the Q-Vegie brand. An e-commerce site has been promoting and selling the products in Dhaka. By doing this, the project can increase the farmer's sales and income as well as sales.

\section{Consumer of the products}

The consumers are divided into four segments namely individuals, group/corporate, superstore and restaurant. Now, the project has worked to increase the customers from each segment. Some of the local village people have purchased Q-vegie products from the farmer directly.

\section{OUTCOMES OF THE PROJECT}

\section{Farmer}

Participant farmers have been able to increase their income gradually through Q-Vegie selling. In Rabi season, we got 72 farmers but in the Kharif-1 season, it was only 42 model farmers for producing quality vegetables. The reasons of decreasing the number of farmers in Kharif-1 were difficulties of pest control, heavy rainfall and needed more labor to produce quality vegetables compared to conventional vegetables.

\section{Production}

It was found that the quantity of production was different between Kharif-1 and Rabi season. The production was satisfactory in Rabi season, but it was deficient in Kharif-1 season. The primary reason of the good production in Rabi season was less intervene of natural calamities and pest infestation. In the case of the Kharif-1 season, the natural calamities were the main cause for low production, and pest infestations play a vital role. In the Kharif-1 season, the country was frequently affected by heavy rain, uneven temperature and natural calamities.

\section{Marketing}

Marketing of quality vegetables have been tough in local village due to lack of awareness about healthy vegetables among local consumers. Local consumers have not been ready to pay the additional price than the conventional price for quality vegetables. However, foreign consumers are willing to give a reasonable price. Foreign consumers and some of the rich consumers are willing to pay higher price because they are well-known about chemical free vegetables as well as health conscious.

\section{Transportation}

Transportation is a considerable problem for selling the products in Dhaka market. Bangladesh has no available refrigerator van service to transport vegetables from the local site to Dhaka. We have to depend on public transports for bringing products to Dhaka. For this reason, the quality of products has been decreased and damaged significant percentage of the products. In addition, the cost of transportation is high which is accountable for the less profit of the farmers. Now the project has been trying to select the site-specific and high-value vegetables to generate more income for the farmers.

\section{Certification of products}

In Bangladesh, there are no facilities to certify raw vegetable products. Consumers have been demanding certification for quality products. The superstores are also interested in quality vegetables, but they want regular supply and certification. A certificate of the quality vegetables is under way which will be the joint effort of BARI and BSMRAU. This certification will create a path to establish a proper system to certify the vegetables.

\section{Seed Sourcing}

Good quality seed is the primary demand from the farmer to produce quality vegetables in the rural area since there is no good source of quality seeds in the rural area. The farmers have to depend on the local vendor for seeds. Those seeds are not always good in quality. The project has been trying to establish a link to seed supplier in local area via QVE to ensure the availability of the good quality seeds in the local area. In addition, the project has been encouraging the local seller to collect quality seeds from the authentic source.

\section{Composting}

The resources for composting have been decreasing in the rural area. The farmers have to depend on limited natural resources to produce compost. The cow dung is not available in all sites to produce compost. The farmers have to depend on poultry manure to produce compost, but it is not safe for quality vegetable cultivation. The model farmers are facing serious problem to collect resources to produce compost for using in the field. The good quality compost was not possible to prepare due to lack of proper composting resources. The project has been trying to increase the production by incorporating vermicompost (the product of composting different decomposable materials by using worms) and organic compost which is prepared by farmers.

\section{Information source}

The good source of information is rare in the rural area. Farmers mainly depend on the local seller of pesticide and fertilizer for their information. The project has 
been helping the farmers to get proper information and introduce them with modern cultivation technologies by using the power of ICT. But the ignorance is the main obstacle to accepting the deliveries from the project. QVE has been working to minimize this ignorance obstacle by helping farmers regularly and showing the benefits of modern technologies.

\section{CONCLUSION}

SENSE project has disseminated the agricultural and marketing information by taking help from QVE and ICT applications in QVMC. Farmers can acquire right information to increase production and protect their products from different problems by using the ICT tools. The farmers have produced quality vegetables based on consumer interest and sells their products at good price. Currently, the project has been working for identifying the delivery mechanism of the products among consumers, the alternative of poor quality compost due to lack of composting materials and the good source of seeds for the farmer in the rural area. Also, the project has been planning to adopt the high profitable vegetables to hold the interest of the farmers despite of different problems such as heavy rain and pest infestation. The project has been trying to develop a certification process to ensure the safety of the farmer products by testing the products in the laboratory of BSMRAU and BARI.

\section{ACKNOWLEDGEMENT}

The authors are thankful to BSMRAU, WIN, GCC and BARI authority for their excellent cooperation in implementing the project. In addition we received generous support from JICA. Here we would like to express the deepest appreciation to all of the organizations.

\section{REFEREENCES}

Hossain, A. and M. Rahman 2012 Development Strategy for the Disadvantaged Youth in Rural Area of Bangladesh. European Scientific Journal, 8(22): 62-75

Hossain, M. A., M. Moniruzzaman and M. A. Islam 2010 Urban Environment Health in Mondal, M. H. 2010 Crop Agriculture of Bangladesh: Challenges and Opportunities. Bangladesh Journal of Agricultural Research, 35(2): 235-245

Okonwu, K. and S. I. Menash 2012 Effects of NPK (15:15:15) Fertilizer on Some Growth Indices of Pumpkin. Asian Journal of Agricultural Research, 6(3): 137-143

Rahman, M. M., G. K. M. M. Rahman, M. S. I. Afrad and S. Islam 2014 Effect of Organic Composts in Red Amaranth and Spinach Productivity and Soil Fertility. Journal of Environmental Science and Natural Resources, 7(2): 1-6 